\title{
FROM CONFRONTATION TO A DIALOGUE: THE DYNAMICS OF RELATIONSHIP BETWEEN THE RUSSIAN ORTHODOX CHURCH AND THE STATE (1917-1980)
}

\author{
Evguenia Belyaeva $^{1^{*}}$, Lyubov Chumarova ${ }^{2}$, Bulat Fakhrutdinov ${ }^{3}$, Anastasia Fakhrutdinova ${ }^{4}$ \\ ${ }^{1}$ Candidate of Philosophical Sciences, Associate Professor, ${ }^{2}$ Candidate of Pedagogical Sciences, Associate Professor, \\ ${ }^{3}$ Postgraduate, ${ }^{4}$ Doctor of Pedagogical Sciences, Associate Professor, Kazan Federal University, Russia. \\ Email: "zhenchum@gmail.com, chumarova@yandex.ru, avfach@mail.ru, avfach@mail.ru
}

Article History: Received on $15^{\text {th }}$ July 2019, Revised on $30^{\text {th }}$ August 2019, Published on $18^{\text {th }}$ September 2019

\begin{abstract}
Purpose of the Study: The aim of the research is to study the tendencies and potential of the church-state relationship at a critical juncture of the great political transformations. An objective need to analyze the past experience of church-state interrelations in Russia and to identify social and cultural role of church as the embodiment of religion served as the incentive for the present study. The article considers church-state relationship under the Soviet regime, the tragedy of their coexistence, reflected in a strong opposition, oppression and almost complete liquidation of the church, and, as a result, its accommodation in relations with the government within that period.
\end{abstract}

Methodology: The authors used philosophical analysis of the church-state interaction, historicism and comparison principles enabling to consider its dynamics and evolution trends within the defined period. The researchers make the presumption that church-state relationship should be maintained on a cultural dialogue and cooperation basis in contrast with prior politicizing it.

Result: The authors prove the provision that state performs not only external social function of organization and subjugation, but, in fact, defines moral criteria of living as a community of like-minded individuals. The conclusion about purely utilitarian and politicized perception of the social position of the church by Soviet state is drawn.

Implications: Theoretical implication of the study is promotion of the further research and development in the direction due to the methods used in the study. The material can also be used within university courses on history, culture theory, cultural studies and sociology of religion, history of world religions.

Novelty: The novelty of the study is manifested in introducing of expanded concepts of church and state in the context of their interaction into scientific circulation.

Keywords: church-state relationship, freedom of faith, cooperation, separation, oppression, patriarch, Bolsheviks, religious, secular.

\section{INTRODUCTION}

In the following the Synod Era of Peter I 200 years of the church's existence in the Russian state, it had been experiencing deepening pressure from the state power, and was almost deprived of self-government. However, Orthodoxy, as the religion and ideology of the Russian people, remained a leading force in the spiritual life (Fakhrutdinova, Mefodeva, Makhmutova, 2017), and Russian emperors served as its defenders and patrons. Despite the fact that the state authorities breached the principle of 'symphony of powers', Russian Orthodox Church sought to maintain and strengthen it.

It is of crucial importance to understand the atmosphere of the break moment in church-state interaction and the implications leading to the reorientation in society's thinking. By the end of the XIX - beginning of the XX century there had been various views on the issue of religion and freedom of faith in Russia. As S.I. Odintsov (Odintsov, 1991) points out in his monograph, liberal intellectuals argued in favour of the reformation of the church-state relationship, overcoming the feudal legacy (Arzhantseva, Gilmutdinova, Nikolaeva, Yamshanova, 2017) in the religious policy of the state, though not supporting a complete separation of church from the state. The Tzar Government and state Orthodox Church strived to continue the alliance, and, finally, Socialist movement, gaining power, especially the Bolsheviks, upholder the principle of separation of church from the state and school from church.

The events that took place in 1917, turned around not only economical, political and cultural life in Russia, but also the existing order of church-state relations up to the end of the Soviet rule with a dominant 'cuius regio, eius religio' (subjects should follow the religion of their ruler) manifested in forcing the church be capitulating and consistent with the new state policy. According to A.N. Berdyaev in his work "The origins and meaning of the Russian communism" (Berdyaev, 2016), Soviet power was sacred and considered the church to be a dangerous competitor.

The controversial issue of the church-state interaction attracts attention of historians, theologians, and philosophers. The greatest number of latest works are devoted to the history of church-state relationship: monographs by V.A. Alekseev, A. Nikolin, M.I. Odintsov (Alekseev, 1992; Nikolin,1997; Odintsov, 1989) and others. The Russian religious philosophers 
S.N. Bulgakov, S.L. Frank, V.S. Soloviev (Bulgakov, 1991; Frank, 1992; Soloviev, 1989; Volgin, 2015) dwelled upon the church's social role and social essence of the state in their works. The issue of the religion's influence on the spiritual and moral social development is being covered by L.A. Morozova, D.V. Pospelovskiy (Morozova, 1995; Pospelovskiy, 1995);historical and politological studies of the relationship between the Russian Orthodox Church and the state were undertaken by R. M. Akhmedov( $\underline{\text { Akhmedov,2001). }}$.

We have chosen the Soviet period, a challenging time for church-state interaction experience, as the object of the analysis in order to study the tendencies and potential of the church-state relationship, taking into account the extreme dynamics and perverse evolution of the interrelations between the 2 social institutions in 1917-1980.

\section{MATERIALS AND METHODS}

The object of the research is church-state relationship in Russian society under Soviet regime (1917-1980).The subject of the research are historic evolution and tendencies of church-state interrelations.

The aim of the study is to consider the dynamics of church-state relationship in the context of political, social and economic transformation in Russia after the October revolution in 1917.

The methodological basis was formed by:

- Philosophical analysis of the church-state relationship, enabling to consider their evolution and the underlying reasons of the changes;

- Historicism principle, making it possible to demonstrate the extreme forms of the interaction experience caused by particular historic conditions;

- Comparison principle, enabling to identify the peculiarities of the church-state relationship in the XX century opposed to that in a prior period.

\section{RESULTS AND DISCUSSION}

The bourgeois-democratic revolution made the church and the government face the necessity to define the principles of their relations. Aiming to clarify the issue, the Interim government adopted the law on the religious freedom and separation the church from the state (Gidulyanov, 1926) claiming to strive for limiting the church's influence in a liberal democratic state and regulating the church-state relationship according to Western European standards.

The church completely rejected these regulations, which was claimed on the Local Council of the Russian Orthodox Church. The papers of the Council contain the evidence of the church's attempt to settle crucial issues of church-state relationship through a dialogue (Nikolin, 1997). Nevertheless, the Interim authorities managed to assert the principle of church's separation from the state and freedom of religion, paving the way to abolishing the church, denominational indifference and promotion of atheism.

The next stage in church-state relationship begins in the time of the October Socialist revolution and the Bolsheviks coming to power.

This period is characterized by an active attack on the church. In response to the church's efforts to preserve alliance and special position in society, the government adopts the Decree on separation of church from state and school from church (Mefodeva, Khairutdinov, Fakhrutdinova, 2017), which gave the green light to theomachists. It is noteworthy that the idea of separation of church from the state was actively debated and supported by the representatives of the 'persecuted' and 'tolerant' religions - Muslims, Old-Believers, Catholics, Baptists (Mefodeva, Fakhrutdinova, Ukhimenko, Valeeva, 2017), etc. The Bolsheviks, in their turn, being confident in the defamation of the clergy's 'political image' and drawing on the growing anti-clerical attitudes in the society, counted on a fast and painless introduction of the Decree. But their hopes failed. The Decree faced strong opposition not only among church authorities and representatives, but also with a huge mass of believers, especially peasantry, which didn't want to put up with secularization of their lifestyle, breaking 'immutable' and 'consecrated' by the Orthodox canons patterns of 'life of faith'.

From January to April 1918 Russia witnessed massive Christian processions, celebrating Mass as acts of support of the church, the government was petitioned to abolish the separation of church from the state and school from church, moreover, it was threatened with a popular uprising in case of its refusal to cooperate. Thus the church openly demonstrated its disobedience and reluctance to meet the state demands. The church announced the Bolsheviks' government to be anathema (Patriarch Tikhon) (Vostryshev, 2009). The Decree was considered by church as the starting point of de-Christianization of Russia, destruction of the centuries-old way of church communities' living and the whole order of Russian social life as well as a threat to the national culture. Thus the church transferred to open opposition and confrontation with the Bolshevicks' regime.

In its turn the government evaluated the church's steps as internal contra revolutionary activity, tightened economic, political and physical measures against the church, setting course for its breakdown from within. The period 1918-1925 the government claiming its loyalty and democracy, implemented an unprecedented policy against the church. 
Under these circumstances the Metropolitan Sergiy (Patriarch Tikhon's successor) addresses the authorities with the Declaration on the clergy's willingness to cooperate with the Soviet state, share its 'joys and successes', 'ups and downs'.

This statement was the culmination of the confrontation in the church-state relationship, serving as the beginning of its end.

Nevertheless, it's worth mentioning that this moment marked the start of the period of gradual and complete church's subjugation by the state accompanied by constant limitation of its rights and social position, lasting up to the eighties.

The World War II was a special time within this period. Under the threat of the Soviet Union's destruction the Stalin's government turned to the church as an organization, able to consolidate the nation (Yakunin, 2001). And the church demonstrated its power and allegiance to the state, signaling the presence of the religious potential of the society that could be used in favor of the state.

Through the whole post-war period (1960s-1980s) the state, whereas claiming the contrary on the international arena, the state never stopped practicing total control of the church activities and even trained 'pro-governmental' personnel among priests and church ideologists (Alekseev, 1992). It resulted in the concept of "Christian communism" (Kopanitsa, 1974), proposed by church ideologists and justifying revolutions, arranging earthly life in the form of 'fair' social and economic structures (socialism, communism), interference in other countries' affairs excused by the support of the national liberation movements and so on, which is contrary to the fundamental Christian principles: search for the God's kingdom as spiritual support in everyday existence and moral development as means to fight public injustice (Bulgakov, 1991)

At the same time, we believe, that the "Christian communism" concept (which still received no official approval) was directed to solve the core contradiction, lying in the basis of church-state interaction - to combine 'celestial' and 'earthly' matters, which has a positive significance despite its contradictory and conciliatory approach.

In conclusion we should say that the state strived to politicize the church-state relationship and regulate it with the help of secular laws.

\section{CONCLUSIONS}

- There had been an unsettled issue of the freedom of faith in pre-revolutionary Russia and a number of social groups favored a cardinal change in church-state relationship's direction as the old patriarchal system seemed outdated on the threshold of social reforms.

- Having gained power, the Communists took the advantage of the opportunity to separate church from the state and school from the church, which eliminated all leverages of the church influence on the Russian society.

- Together with feudal prejudices some valuable cultural codes preserved in the church tradition were altogether lost. Children education and upbringing, matrimonial ethics, professional, individual and national moral principles were ruined and replaced with new ones.

- Being dependent of the state and public attitudes, the church finally had abandoned resistance and opposition policy and looked for a dialogue with authorities.

- The church-state partnership, though, could be called one-sided, for it was aimed at using the church's influence on the believers and sympathizers to strengthen the governmental power in society. The most illustrative example of the conformist position of the church within this period was the concept of "Christian Communism" which emerged in the 1960s.

- The state power purposefully undermined the social significance of the church (unless it was needed to help the state in critical situations like wars, etc.) in order to exercise total control of the organization.

- The church - state interaction during the Soviet period (1917-1980) was a radical embodiment of the so-called 'caesaro-papism principle', when the state persecuted the church, roughly interfered in its affairs and used its authority for political purposes.

\section{ACKNOWLEDGEMENTS}

The work is performed according to the Russian Government Program of Competitive Growth of Kazan Federal University.

\section{REFERENCES}

1. Akhmedov, R.M. (2001). The state and church in the Russian society of XX century: historic and legal research/ PhD Thesis (Law). Kazan.

2. Alekseev, V.A. (1992) Is storming heaven cancelled? Critical essays on the history of the anti-religious struggle in the USSR/ V.A. Alekseev. Moscow: Rossiya Molodaya.

3. Arzhantseva, N.V., Gilmutdinova, I.V., Nikolaeva, O.A., Yamshanova, E.V. (2017). Influence of college of pontiffs on public life in the Roman Republic in VI-I centuries BC. Man in India. №97 (9). 95-100. 
4. Berdyaev, N.A. (2016). The origins and meaning of the Russian communism. Saint-Petersburg: Azbuka.

5. Bulgakov, S.N. (1991). Christian Socialism. Novosibirsk.

6. Fakhrutdinova, A.V, Mefodeva, M.A., Makhmutova, M. (2017). The idea of citizenship education in Russian universities: modern approach and content.: INTED Proceedings: 11th International Technology, Education and Development Conference. 4637-4642. https://doi.org/10.21125/inted.2017.1091

7. Frank, S.L. (1992). The spiritual foundations of society. Moscow.

8. Gidulyanov, P.V. (1926) Separation of church from the state in the USSR: complete collection of decrees, ministerial orders and the RSFSR Supreme Court rulings. -Third Edition. Moscow: Yurizdat NKYU RSFSR.

9. Kopanitsa, M.M. (1974) Criticism of the concept of "Communist christianity" of the modern Russian orthodoxy. Kharkov: Vishcha Shkola.

10. Mefodeva, M., Khairutdinov R., Fakhrutdinova A. (2017) Value education philosophy in Russia and India.: Proceedings of $9^{\text {th }}$ International Conference on Education and New Learning Technologies 3-5 July, IATED, Barcelona, Spain. 9886-9891 https://doi.org/10.21125/edulearn.2017.0871

11. Mefodeva, M.A., Fakhrutdinova, A.V., Ukhimenko, A.N., Valeeva, G.F. (2017) Historical perspectives of spiritual and moral education in India. Man in India, Vol.97, Is.8. 71-77

12. Morozova, L.A. (1995). The state and church: the specifics of relationship. Moscow. State and Law.

13. Nikolin, A. (1997) The church and state (the history of legal relationship). Published by Sretenskiy Monastery.

14. Odintsov, M.I. (1989). 7 Decades' way: from confrontation to cooperation: on the way to freedom of conscience. Moscow.

15. Odintsov, M.I. (1991). State and church (the history of relationship.1917-1938). - Moscow: Znaniye.

16. Pospelovskiy, D.V. (1995). Russian Orthodox Church in the XX century. Moscow.

17. Soloviev, V.S. (1989). Works. 2 Volumes, Vol.2. Moscow. 549-561

18. Volgin, O.S. (2015) Vladimir Soloviev about the meaning of the state. Philosophical Sciences. №8. 7-20.

19. Vostryshev, M. (2009). Patriarch Tikhon. Moscow.:Molodaya Gvardiya.

20. Yakunin V.N. (2001). The position and activity of the Russian Orthodox Church during the Great Patriotic War 1941-1945. Samara: Samara University Press. 